\title{
The impact of designing visual learning situations in the development of emotional intelligence and adaptive behavior for the mentally handicapped who can learn
}

\author{
Prof. Asmaa Elsayed Mohamed Abdel Samad \\ Instructor, Education Technology Department, Faculty of Education - Helwan University
}

\begin{abstract}
The research aims to measure the impact of the design of visual learning situations based on animation in the development of emotional intelligence and adaptive behavior of children with mental disabilities who are capable of learning. This research was followed by a semi-experiential approach. The experimental group, which was studied using the depicted situations, was superior in the measure of the visual emotional intelligence and the measure of adaptive behavior compared to the control group that did not suffer from these attitudes. The results of the study also revealed a correlation between emotional intelligence and adaptive behavior.
\end{abstract}

Keywords: visual learning - emotional intelligence - mentally handicapped

DOI: $10.7176 / \mathrm{JEP} / 10-17-14$

Publication date:June $30^{\text {th }} 2019$

\section{Introduction:}

The field of people with special needs of the most important areas in which it attaches our nation great interest, the United Nations statistics indicated that there are more than 500 million disabled people around the world, $80 \%$ of them located in the range of developing countries, and represents a mental disability, $8.5 \%$ of the size of these disabilities in general ( Iman Mohammed al-Kashef, 2001 , p. 11), mental retardation means a decline in the rate of mental development, so that the child is unable to adapt to itself and the environment surrounding it ( Abd al-Muttalib Amin, 2005 , p. 35).

And within the framework of what he confirmed Mayer \& Salovey (2000, P.65) However, the individual's emotional intelligence contributes to his intellectual, emotional and social happiness, which helps him adapt to life and successfully cope with problems. Therefore, the present research seeks to design visual learning situations based on animation to develop the emotional intelligence and adaptive behavior of mentally handicapped children who are able to learn, in the light of the complementary theory. Nawal Mohie Mohammed (2016) indicated that learners in general need to acquire skills and abilities at the same time, they need to translate this knowledge and skills into behaviors in different aspects of life as representing the emotional side parallel to the mental aspect.

With increasing access to technology and the fact that it is available to many categories of users who always believe that children lack sufficient knowledge and how to deal with society. With these growing societal problems, the role of the family in educating children and developing their skills through normal household activities has been shrinking, creating a real need for an alternative solution to support and encourage children to learn and develop their own skills better. As the child needs and the skills and abilities, and the activities, with the need to take into account the different factors that may affect the attitudes of learning (El Said, Hany M, 2018)

The importance of developing learning attitudes in the early stages of children in general and the mentally handicapped, especially those who are particularly able to learn, has become a developmental necessity for the lives of these children, and for the development of their personalities in their emotional and social dimensions; Muhammad Mahmoud Al-Hilla (1999, p. 33) Which is concerned with understanding the methods of design, improvement, development and continuation of education by following the best educational methods that will achieve the desired results in accordance with certain conditions. The design of learning situations is based on mentally handicapped children who can learn on the theory of flexibility defined Cognitive Flexibility, which emphasizes that methods that rely on indoctrination do not allow the formation of knowledge at different levels, and that the learner must deal with information to know something or solve a certain problem (Mustafa Salama Abdel Basit, 2017 p. 85) 
and emphasizes the theory of social growth of Vygotsky on That the individual in his learning is influenced by the environment (learning environment), which provides visual learning situations based on animation by presenting real life situations, may be exposed to the disabled child and should improve the behavior in these situations and employ his intelligence and emotional adaptations when it occurs, The educational design of these institutions (Claudia Judessi, et al., 2014, p. 100). From the earliest age, the types of knowledge acquired by the child are between what is perceived It is a practical special procedure to what is a general concept of my statement, it interacts and integrates with each other, both at the level of construction or development, or at the level of learning and moving from one situation to another, the child needs to learn and solve the problems that face to 1. mental processes which are concrete actions incorporated by the child in His knowledge structure internally, became on Form of representations employed in different situations. Mental entities that are preserved in the long-term memory of concepts related to things, events, actions and relationships, which take the form of categories or theories.

The previous studies recommended the study of the effectiveness of educational attitudes in the construction of knowledge and life skills in children with special needs, such as the study of Sultan Faleh Saad et al. (2016). During which the standards of designing digital educational positions within electronic training environments. The design of educational situations for people with special needs in general, and the mentally disabled, who are able to learn in particular is a very complex task. The educational designer must have a great deal of thinking skills to deal with the problems facing the learner in educational situations and practical applications. Situational learning theory considered the learning situations is a set of knowledge and skills that students learn in contexts that reflect how knowledge is acquired and applied in daily life situations.

Thus, a set of conditions must be created in the learning environment to help make learning stand-by, so that learners can deal with the vagueness of learning in the real world. Such attitudes cannot be taken away from the situation in which they occur (Muhammad Saeed Al-Aklabi, 2018 et al., P. 71).

The study of Sahar Shaaban Musleh (2011); King, Heidi \& others (2000); Yusreya Abdel Hamid Faraj (2006); Moallem, Mahuaz (1998) referred that The importance of using individual learning methods in teaching the design of educational situations, As confirmed by the study of Ruffini, M (2000) that the good design of learning situations ensures that students' interest is maintained and motivated to continue learning. The educational situations are a situation in which the individual learns through his / her experience with a prior experience in the light of his / her previous experiences in order to bring new experiences to the future. (Sahar Shaaban Musleh, 2011, p. 366).

Children with mental disabilities suffer from a range of problems identified by Jamal Mohammed Al-Khatib (2008) as follows:

\section{Attention Problems}

Mentally disabled children are short of attention, easily distracted, short-sighted, and have great difficulties in selective attention, that is, focusing on important dimensions of the task, ignoring insignificant dimensions. They need more time and exercise than Other individuals. Special educational literature suggests the following treatment methods for attention problems among mentally disabled individuals, including:

(A) the use of stimuli of clear dimensions,

(B) employ the skills analysis method and transition from easy to gradually difficult,

(C) Use appropriate methods to help the individual to pay attention to dimensions of importance (eg, hints and guidance);

(D) Use of lighting, contrasting colors or sound stimulators to focus attention,

(E) Remove all distractions that are unrelated to the task required,

(F) Promote appropriate responses from the individual,

Besides that, children also suffer from transfer of learning problems, which are meant to transfer learning, training, or the impact of skill learning has on individual's learning another skill, or the ability of the individual to employ what he learned in a previous situation in new situations with similar elements. Children with mental disabilities, especially those with moderate and severe retardation, face great difficulties in transferring the skills they learn in a situation to other similar situations. Teachers and learners should understand this fact, planning ahead of time to make the generalization or transmission of the impact of training (from school to home, from 
the resource room to the regular classroom, and so on). Without effective programming, the probability of mainstreaming is minimal. The ability of mentally disabled children to acquire skills through Incidental Learning, i.e., unintended learning resulting from routine daily experiences and observations, is not that of ordinary students. In Memory Problems and inability to remember, the severity of the inability to remember increases with the severity of mental retardation, and One of the most important aspects of memory failure in these children is short-term memory. While Long Term Memory is often normal when information is entered. These memory problems are due to inadequate educational strategies used by these people. Specifically, they have considerable difficulties in selective attention and in the use of Mediation and organizational strategies, as well as in compiling information when attempting to store them for retrieval,

The present research sought to design visual learning situations based on animation to help these children to acquire emotional intelligence and ability to adapt to different life situations, which show their importance through the nature of changing attitudes, which make the mentally disabled child need to deal with those changes in the right way, and for the handling and proper conduct. The results of the Smith, and Kortering study (2006) found the effectiveness of the computer in completing a set of well-planned tasks for the mentally disabled. A comparison was made between a specially designed interface to make computer use more accessible to users with mental disabilities. The study sample consisted of 32 students.

The results of the study showed that the joint students made fewer errors $(\alpha=001.0)$ and needed less help $(\alpha=$ 001.0) while using the specialized program interface than students who had received traditional education. BarOn (2006) defines emotional intelligence as (Mayer, Salovey \& Caruso 2000) defines the ability to understand emotions, self-emotions, understanding and distinguishes others' emotions and emotions, and the use of information to guide an individual's thinking and actions, as he knows Bazhou, Shapiro Batshaw \& Shapiro (2002, p. 187) Adaptive behavior is a set of social, scientific and conceptual skills that help individuals in their daily lives. They include a variety of behaviors including: the ability to communicate effectively, interact with others, as well as the ability to wear clothes and maintain personal hygiene, so we had to teach the mentally disabled child the sound foundations avoided by failure to deal with different situations. This is accomplished through acquiring different skills, because it integrates school and life, and embodies the function of learning. It connects to the needs, daily attitudes, and needs of the community, and gives him the opportunity to live a better life, especially in this age of explosive knowledge and technological sophistication. Which requires the preparation of individuals who are able to adapt and interact with these variables, gain direct experience through direct interaction with people and phenomena, make learning meaningful, help them enhance self-confidence, and overcome the problems of life Treat them wisely, develop their personality, help them gain experience, and allow them to take advantage of all the available resources that contribute to their development at all levels. In order to achieve the emotional intelligence of children with mental disabilities who are able to learn and adapt in different situations, this requires consideration of the following:

- Learning depends on the attitudes of visual learning on both the correct scientific logic, and hard technical training, which leads to the rapid learning of these situations, with the economy in the mental and physical effort.

- Practice: Because it is a corner of the acquisition of these situations, so they use the central senses, the movement necessary for behavioral performance.

- The practice should be available in accordance with the quality and requirements of the intended situations.

- Repetition: The repetition of the desired situations becomes a habit, and this habit becomes part of the parts of the disabled child, which he effectively exercises in the different situations he is exposed to (Huda Saad al-Din, 2007, Abd al-Salam al-Najin, 2010, p. 42).

- Learning depends on the attitudes of visual learning on both the correct scientific logic, and hard technical training, which leads to the rapid learning of these situations, with the economy in the mental and physical effort.

- Practice: Because it is a corner of the acquisition of these situations, so they use the central senses, the movement necessary for behavioral performance.

- The practice should be available in accordance with the quality and requirements of the intended situations.

- Repetition: The repetition of the desired situations becomes a habit, and this habit becomes part of the parts of the disabled child, which he effectively exercises in the different situations he is exposed to (Huda Saad al-Din, 2007, Abd al-Salam al-Najin, 2010, p. 42). 


\section{Research objectives and questions:}

The aim of this research is to measure the impact of visual learning based on animation in the development of emotional intelligence and adaptive behavior of mentally handicapped children. This study attempts to answer the following questions:

- What is the impact of the design of visual learning based on animation in the development of emotional intelligence for mentally disabled children who can learn?

- What is the impact of the design of visual learning based on animation in the development of adaptive behavior of children with mental disabilities who can learn?

- What is the relationship between emotional intelligence and adaptive behavior for mentally disabled children who can learn?

3. Methodology:

The researcher used this research in the category of developmental research by using three methods:

1. Descriptive approach in the study and analysis stage.

2. Methodology development of educational systems in the design and development stages.

3. The Semi-Experimental Approach in Measuring the Effectiveness of Learning Situations in the Assessment Phase.

\section{Research Sample:}

The researcher relied on a sample of (40) mentally handicapped children who are able to learn at the School of Intellectual Education in the city of 15 May, and their ages ranged from 6: 5 years, divided into two groups, control and experimental to apply the research experience and answer their questions.

\section{Research Tools:}

In this research, the researcher relied on semi-experimental design with the following tools:

1. Visual Emotional Intelligence Preparation Scale (Yusuf Mohamed Yusuf.2017), and consists the scale from:

1/1 the first part: The Cameraman scale For Emotional intelligence:

Phrases about (25) Visual Situations distributed on Elements. The five which Golman put it down to express about Emotional Intelligence, and each item consists of five Situations, and Each Attitude From Picture followed by Two photos For choice, In Number From Attitudes Be There Two photos Just to choose Child Image which crosses what inside according to his actions in a Like this is Attitudes, It takes Child On the answer Right 2 degrees and zero to answer wrong, Therefore the maximum score for the part the first ( 50 degrees )

1/2 The second part: Teacher especially Form Note To measure Emotional Intelligence:

Which Form Consists Of (25) Distributed phrase also on elements, the five which put it down by Golman's expression About Emotional Intelligence, and specializes for each item Five Phrases, and the teacher selects what between three options, which are (applies Much, apply Sometimes .and Never Applies), And take Degrees (2-1-0) .But in a negative phrases which (7-8-9-10) take Degrees (2-1-0) and so on .

Be Maximum Class for the part your second in the form (50 degrees), so be total to the Cameraman scale degrees for emotional intelligence (100 Degree)

\section{Adaptive Behavior Scale:}

The researcher completed adaptive behavioral measures, which are Form Consists Of (40) words Distributed Also On Elements Which measures adaptive behavior, each element is concerned with a set of terms, and is chosen the teacher what between four options, which are ) Applies Much - Applies Sometimes - Rarely applicable - Never apply, take degrees (3-2-1-0), thus the total sum of the degrees of adaptive behavior measure (120 degrees).

- pre-application of the research tools:

- Applying the IQ Scale:

The objective of the pre-scale of the emotional intelligence criterion was to ascertain the parity of the two groups in the level of emotional intelligence prior to the research experiment.

The pre- scale was applied to the experimental and control groups. The results were monitored and then statistically treated using $\mathrm{T}$ test. The results were as shown in Table (1)

The results of Table (1) show that there is no statistically significant difference between the experimental and control groups in the pre- application of the emotional intelligence scale. The calculated value of (T) is (1.303) and is not significant at 0.05 level. This means that the two groups are equal in the IQ scores Before experimentation. 


\section{- Research experience and presentation of visual learning situations on mentally disabled children who are able to learn:}

The visual learning situations, which were designed as problems for children with mental disabilities, which can be taught by the experimental group, were presented with research, which requires solutions by employing the emotional intelligence of these children. The learning situations were formed from 10 situations. Each situation was a problem that needs to be solved. The child has three alternatives to think about until he reaches a suitable solution to the situation presented to him, and with the help of the teacher, the child can choose the correct solution to the situation, and then after the end of each situations presents a similar situation and ask him to think the solution alone as follows:

\section{- post- application for research tools:}

After the application of the research experience and presentation of visual situations on children with mental disabilities in the experimental group, was completed Application of emotional intelligence scale, where Presents Of the child Section Cameraman For scale, It is based on the examiner to recording Child responses in a Correction key Attached With the scale, And so on without Help Except With Some Cases that need to help in a sometime, and for the Teacher observation form , The teacher Read Phrases, And from Then he Records his responses and class selection which represent destination a look in This Child, and when applying the Adaptive Behavior Scale, the teacher measured Adaptive behavior for the same Child which done Cameraman Emotional Intelligence Scale, Where the teacher read Phrases, and from Then record their responses And class selection which represent destination a look in This Child .

\section{Research procedures:}

The experiment was conducted in a classroom in the schools of intellectual education in the city of 15 May, Cairo. Each participant in the experiment completed learning about the visual learning situations during the required time. Before the experiment, written approval was obtained from the principal, the participants were then given a brief description of the research, including their goals, procedures and privacy measures.

After the experiment, the principal wanted to obtain a copy of the visual learning situations of the questionnaire to apply them in the future with new children who will join the intellectual education, the researcher has given a copy.

\section{Results and discussion:}

In order to answer the first question of the research on the influence of the design of visual learning situations based on animation in the development of the emotional intelligence of mentally disabled children who are able to learn, the value of $(\mathrm{T})$ and the significance of the difference between the mean scores of the students of the first experimental group In the post-application to test the cognitive achievement, and Table (2) shows that: Table (2) shows the average score of the students in the experimental group on the average score of the control group students in the post-application of the IQ.

The experimental group obtained an average of 94.15 with a standard deviation of 5.029 while the control group obtained an average of (84.90) (10.637), and the value (T) calculated to indicate the difference between the average scores of the experimental and control groups in the post-application of the IQ of (3.516) function at $(0.05) 2(24.5 \%)$ of the variance in the level of emotional intelligence (dependent variable) is due to the design of the visual learning situations (the independent variable) and the value $(d)=(1.112)$ It expresses the size of the large effect of the independent variable because the value (d) Is greater than 0.8 , indicating that there has been a clear growth in the level of emotional intelligence in the experimental group, as illustrated in the following diagram. In order to answer the second question of the research on the influence of the design of visual learning situations based on animation in the development of adaptive behavior of children with mental disabilities capable of learning, the value of $(\mathrm{T})$ and the extent of its significance were calculated for the difference between the average scores of the students of the control and experimental groups in the post-application of the Adaptive Behavior Scale (3) This explains: Table (3) shows the average score of the students in the experimental group on the average score of the control group students in the post-application of the adaptive behavior measure. The experimental group obtained an average of (110.05) with a standard deviation of (8.642) while the control group got an average of (98.40) (9.202), and the value of (T) calculated to indicate the difference between the average scores of the students of the experimental and experimental groups in the post-application of the adaptive behavior measure which reached (4.127) function at $(0.05)^{2}(30.9 \%)$ of the variation in the level of adaptive behavior (dependent variable) is due to the design of visual learning situations (independent variable) and the value $(d)=(1.305)$ It expresses the size of the large effect of the independent variable because the value (d) Is greater than 0.8 . This indicates that there has been a clear and significant growth in the level of adaptive behavior of experimental students, as illustrated in the following diagram. 
To answer the third question of the study of the effect of the relationship between emotional intelligence and adaptive behavior of mentally handicapped children who are able to learn, the value of Pearson correlation coefficient. Between the grades of students of the two experimental groups separately in the cognitive achievement test and their scores on the post-application enrollment scale.

There was a positive correlation between the degrees of post-application of the control group students in the emotional intelligence scale and their degrees in the adaptive behavior measure.

The Pearson correlation coefficient (0.696) was a function at 0.05 . Figure (4)

There was also a positive correlation between the post-application scores of the experimental group in the emotional intelligence scale and their degrees in the adaptive behavior measure. The correlation coefficient of Pearson (0.518) was a function at 0.05 . Figure (5)

\section{Research Recommendations:}

The goal of the present research to measure the impact of the design of the situations of visual learning based on the animation in the development of emotional intelligence and adaptive behavior for children with mental disabilities who are able to learn, and reached the search results to the superiority of the experimental group which studied the use of comic situations, in the intelligence scale Emotive photographer, and scale adaptive behavior, Compared to the control group that did not experience these attitudes, and the results of the study to the existence of a relationship between emotional intelligence and adaptive behavior, the more emotional intelligence of the mentally disabled child, increased its ability to adapt in the different situations This means that it is necessary to focus on revealing the dimensions of emotional intelligence because of its influential role in developing the ability of these children to solve the problems they face in various aspects of their lives. This is a group that has a lot of capabilities if they are better guided and control their behavior and improve their adaptation to life situations Visual and interactive learning situations have an effective role in attracting their attention. Therefore, the researcher recommends that the design of such situations should be taken into account in accordance with specific steps, procedures and standards, especially the materials and activities that depend on the use of the computer and its networks. Research can provide a reference for the development of learning materials provided for this class. However, as with all experimental research, this study has some limitations.

The most important of these is that these individuals are easily distracted, short-sighted, and have difficulties in selective attention, that is, focusing on dimensions of importance in the task and ignoring insignificant dimensions. They need more time and exercise than other people. Therefore, it is necessary to use stimuli of clear dimensions, use appropriate methods to help them pay attention to the dimensions of importance, remove all distractions or unrelated to the task required, and promote appropriate responses from them. And future research may include the use of eye - tracking to record the concentration of these children during the learning, and the use of their own gestures to achieve maximum interaction with modern technology in line with their mental and physical.

\section{REFERENCES}

1. Abdul Salam Al Najin (2010). Magazine Knowledge (p ) 170, pp. 42-65, Riyadh

2. Abdulmutallab Amin Al-Qaraiti (2005). Psychology of Special Needs and Their Education, Cairo, Dar Al-Fikr Al-Arabi.

3. Ahmed Hussein Abdelmatti, Duaa Mohamed Mustafa, (2000); life skills, Cairo, Dar Sahab .

4. Ahmed Hussein Al-Laqani (1996); Methodology (Foundations - Components - Organization), Dar Alam Books, Amman.

5. Bar-On, R. (2006). The Bar-On Model of Emotional-Social Intelligence (ESI). Journal of Psicothema, $18,13-25$.

6. Batshow, M. , \& Shapiro, B. (2002). Mental Retardation. In ML Batshow (Ed ) children with Disabilities (5 th ed.287-306).Washington Dc: H.paul Brookes Publishing company

7. El Said, Hany M(2018). Interactive Design Technics \& the Future of Learning for Kids, Arab Society for Civilization and Islamic Arts,N.11, PP. 78:68

8. Huda Saad El Din (2007); life skills included in the 10th Grade Technology Course and the extent to which students acquire them.

9. Iman Fouad Al-Kashif (2001). Mental Disability between Neglect and Guidance, Dar Al-Qabba, Cairo.

10. Jamal Mohammed Al-Khatib (2008). Standard Guide to Disability, Special Education and Rehabilitation, Executive Office of GCC Council of Ministers of Labor and Social Affairs.

11. Judy, Claudia, Jaafar, Ashour, Karla, Krishivsky, Mara translation, Ahrshaw (2014). So that learning becomes visible and tangible: children, in learning situations, individual and groups of the Kuwaiti Society for the Advancement of Arab Children, vol. 16, p. 61, pp. 101: 95. 
12. King, Heidi \& others (2000). why Every College Needs an instructional Desiner to Support Faculty Innovation, ERIC Digest, ED 452887,

13. Mayer, J., Salovey, P., \& Caruso, A. (2000). Models of Emotional Intelligence. Handbook of Intelligence, Cambridge University Press.

14. Moallem, Mahuaz (1998). instructional Design Models Research on Teacher Thinking: Toward a New Conceptual Model for Development, ERIC Digest, Ed 397822 ,.

15. Mohamed Mahmoud Al-Hila (1999). Educational Design: Theory and Practice, 1, Amman, Dar AlMaysara.

16. Mohammed Saeed Al-Aklabi, Nabil Gad Azmi, Hussein Bashir Mohammed, Manal Abdel-Al Mabarz (2018). Role Theories Learning Contemporary in a Design Learning Mobile : Revision For literature, magazine reading Knowledge, p 202, Association The Egyptian Read Knowledge, August, pp. 61: 86

17. Mustafa Salama Abdel Basset Serageldin (2017). The impact of two strategies for e-learning to develop the skills of designing educational attitudes and creative thinking among postgraduate students, Journal of the College of Education, vol. 32, p. 2, pp. 133: 71.

18. Nawal Mohie Mohammed Al-Shabasi (2016). Emotional Intelligence and its Relation to Problem Solving in a Sample of Mentally Disabled Persons with Learning Disabilities, Journal of Practical Research in Education, p.17

19. Ruffrni, M. (2000). Systematic planning in the Design of an Educational Web Site Educational technology, 40 (2).

20. Sahar Shaaban Mosleh Mohammed (2011). The necessary situations to design education and e-learning in technology education students, the Conference Skills Scientific Research Seventh of the Assembly Arabic Technology education (Learning And challenges Peoples Arabic: ' Societies Learning Interactive, Egypt, Institute of Educational Studies, Cairo University,

21. Smith, Stephen W. and Kortering, Larry, J. (2006). The Disabilities, Journal of Intellectual and Developmental Disability, v31 n1 p39-46 Mar 2006

22. Sultan Faleh Saad Al-Subaie, Salwa Fathy Mahmoud Al-Masri, Hanaa Mohamed Morsey Jamal Al-Din, Hassan Hussein Gamae (2016). Standards for designing digital educational positions within electronic training environments, p. 173, pp. 147: 125.

23. Yousriya Abdel Hamid Faraj (2006). The difficulties of designing educational attitudes among students of educational technology in faculties of specific education, unpublished $\mathrm{PhD}$ thesis, Faculty of Specific Education, Ain Shams University

Table (1) The value of "T" and the level of significance of the difference between the average grades of students of the two experimental groups in the pre- application of the IQ

\begin{tabular}{|c|c|c|c|c|c|c|c|}
\hline the group & $\begin{array}{c}\text { Students } \\
\text { Number }\end{array}$ & $\begin{array}{c}\text { SMA } \\
(\mathrm{M})\end{array}$ & $\begin{array}{c}\text { Standard } \\
\text { deviation } \\
(\mathrm{P})\end{array}$ & $\begin{array}{c}\text { Degrees of } \\
\text { freedom } \\
(\text { Dr.H) }\end{array}$ & $\begin{array}{c}\text { Values } \\
(\mathrm{T}) \\
\text { calculated }\end{array}$ & $\begin{array}{c}\text { Level of } \\
\text { significance } \\
\text { calculated }\end{array}$ & Significance \\
\hline Control group & 20 & 36.05 & 10.180 & 38 & 1.303 & 0.200 & $\begin{array}{c}\text { Not a function } \\
\text { at level } 0.05\end{array}$ \\
\hline $\begin{array}{c}\text { experimental } \\
\text { group }\end{array}$ & 20 & 31.35 & 12.508 & & \\
\hline
\end{tabular}


Table (2) The value of "T" and the level of significance of the difference between the average grades of Control and experimental groups students in the post-application of the measure of emotional intelligence

\begin{tabular}{|c|c|c|c|c|c|c|c|c|c|c|}
\hline & $\begin{array}{l}\text { Number } \\
\text { the } \\
\text { students } \\
(\mathrm{N}) \\
\end{array}$ & $\begin{array}{l}\text { SMA } \\
\text { (M) }\end{array}$ & $\begin{array}{l}\text { standard } \\
\text { deviation } \\
\text { (P) }\end{array}$ & $\begin{array}{l}\text { Degrees } \\
\quad \text { of } \\
\text { freedom } \\
\text { (Dr.H) }\end{array}$ & $\begin{array}{c}\text { Values } \\
(\mathrm{T}) \\
\text { calculated }\end{array}$ & $\begin{array}{c}\text { Level of } \\
\text { significance } \\
\text { calculated }\end{array}$ & Significance & $\begin{array}{c}\text { Values } \\
2 \eta\end{array}$ & $\begin{array}{c}\text { Values } \\
\mathrm{d}\end{array}$ & $\begin{array}{l}\text { Effect } \\
\text { size }\end{array}$ \\
\hline $\begin{array}{c}\text { Control } \\
\text { group }\end{array}$ & 20 & 84.90 & 10.637 & \multirow[t]{2}{*}{38} & \multirow[t]{2}{*}{3.516} & \multirow[t]{2}{*}{0.001} & \multirow[t]{2}{*}{$\begin{array}{c}\text { A function of } \\
\text { level } 0.05\end{array}$} & \multirow[t]{2}{*}{0.245} & \multirow[t]{2}{*}{1.112} & \multirow[t]{2}{*}{ Large } \\
\hline $\begin{array}{c}\text { The } \\
\text { experimental } \\
\text { group }\end{array}$ & 20 & 94.15 & 5.029 & & & & & & & \\
\hline
\end{tabular}

Table (3) Value of "T" and the level of significance of the difference between the average grades of students of the two experimental groups in the post-application of the engagement scale

\begin{tabular}{|c|c|c|c|c|c|c|c|c|c|c|}
\hline the group & \begin{tabular}{|c|} 
Numbe \\
r \\
the \\
student \\
s \\
(N)
\end{tabular} & $\begin{array}{l}\text { SMA } \\
\text { (M) }\end{array}$ & $\begin{array}{c}\text { standard } \\
\text { deviatio } \\
\mathbf{n} \\
(\mathrm{P})\end{array}$ & \begin{tabular}{|c|} 
Degrees \\
of \\
freedo \\
m \\
(Dr.H)
\end{tabular} & $\begin{array}{l}\text { Values } \\
(\mathrm{T}) \\
\text { calculate } \\
\text { d }\end{array}$ & $\begin{array}{c}\text { Level of } \\
\text { significanc } \\
e \\
\text { calculated }\end{array}$ & $\begin{array}{c}\text { Significanc } \\
\text { e }\end{array}$ & $\begin{array}{c}\text { Value } \\
\mathbf{s} \\
{ }^{2} \eta\end{array}$ & $\begin{array}{c}\text { Value } \\
\text { s } \\
\text { d }\end{array}$ & $\begin{array}{l}\text { Effec } \\
\text { t size }\end{array}$ \\
\hline $\begin{array}{c}\text { The first } \\
\text { pilot } \\
\text { (Individually } \\
\text { ) }\end{array}$ & 20 & 98.40 & 9.202 & \multirow[t]{2}{*}{38} & \multirow[t]{2}{*}{4.127} & \multirow[t]{2}{*}{0.000} & \multirow[t]{2}{*}{$\begin{array}{l}\text { A function } \\
\text { of level } 0.05\end{array}$} & \multirow[t]{2}{*}{0.309} & \multirow[t]{2}{*}{1.305} & \multirow[t]{2}{*}{$\begin{array}{c}\text { Larg } \\
\text { e }\end{array}$} \\
\hline $\begin{array}{c}\text { The second } \\
\text { trial } \\
\text { (Multiple) }\end{array}$ & 20 & $\begin{array}{c}110.0 \\
5\end{array}$ & 8.642 & & & & & & & \\
\hline
\end{tabular}

Table (4) The correlation coefficient between the grades of students of the two experimental groups at the measure of emotional intelligence and their degrees on the scale of adaptive behavior in the post-application

\begin{tabular}{|c|c|c|c|c|}
\hline the group & $\begin{array}{c}\text { The parties to the } \\
\text { relationship }\end{array}$ & $\begin{array}{c}\text { Number of } \\
\text { students } \\
\text { (N) }\end{array}$ & $\begin{array}{c}\text { Pearson correlation } \\
\text { coefficient } \\
\text { (T) }\end{array}$ & $\begin{array}{c}\text { Level of } \\
\text { significance }\end{array}$ \\
\hline Control group & $\begin{array}{c}\text { Intuitive intelligence } \\
\text { Adaptive behavior }\end{array}$ & 20 & 0.696 & 0.05 \\
\hline $\begin{array}{c}\text { The experimental } \\
\text { group }\end{array}$ & $\begin{array}{c}\text { Intuitive intelligence } \\
\text { Adaptive behavior }\end{array}$ & 20 & 0.518 & 0.05 \\
\hline
\end{tabular}



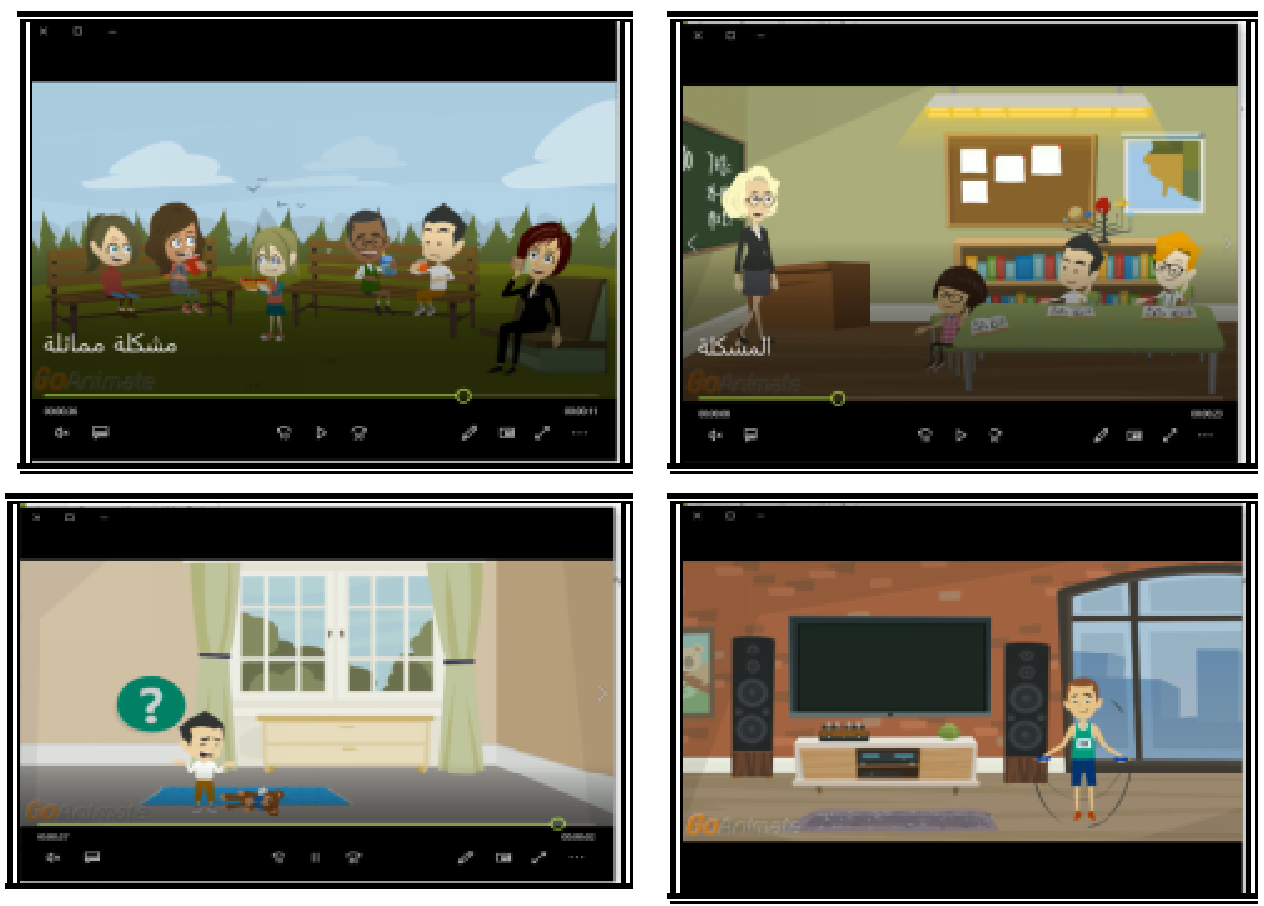

Figure 1: A model of learning situations designed in the form of problems that require solutions and a problem

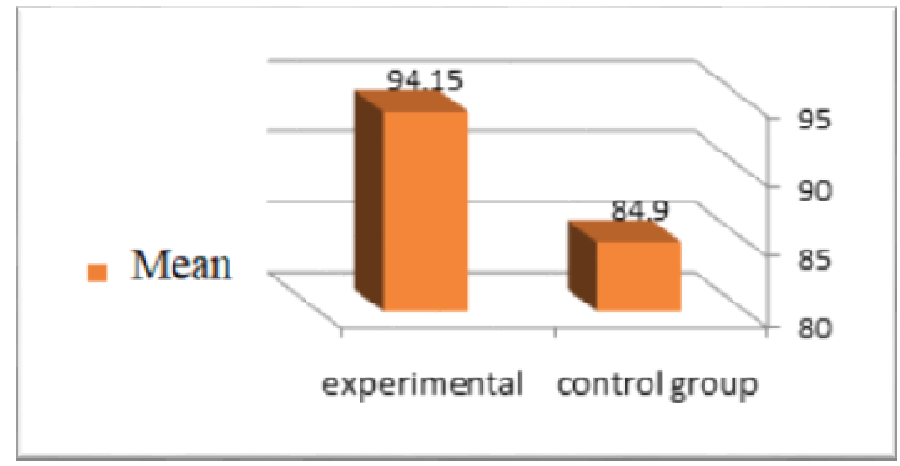

Figure (2) Diagram showing the histogram of the mean of the post application degrees for the emotional intelligence of the control and experimental groups 


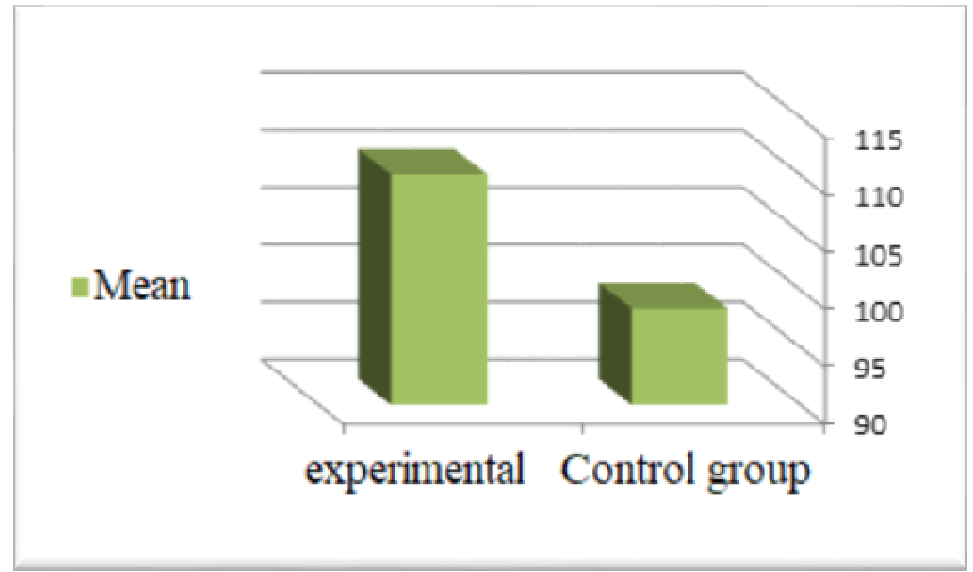

Figure (3) Diagram showing the histogram of the mean of the post application degrees for the adaptive behavior measure of the experimental and control groups

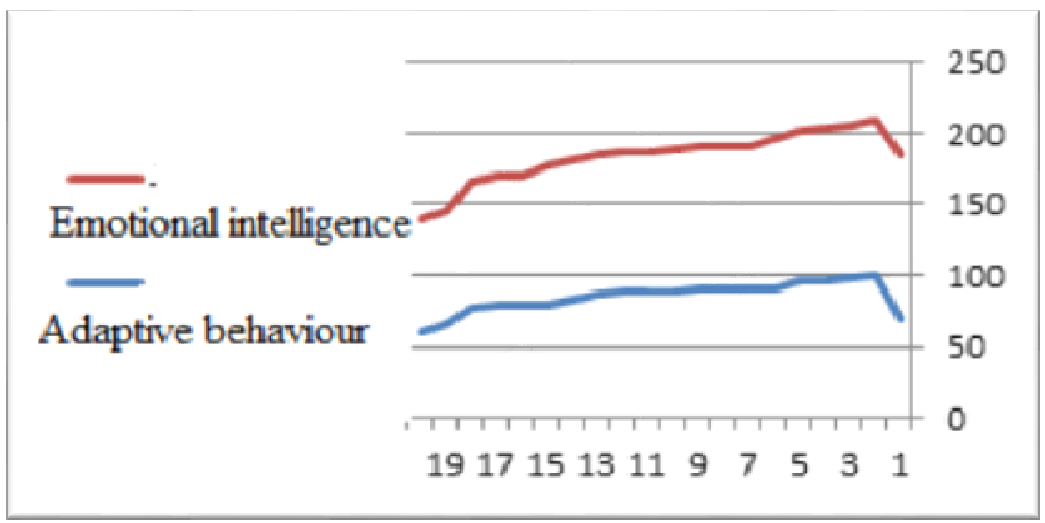

Figure (4) A diagram showing the correlation between student scores

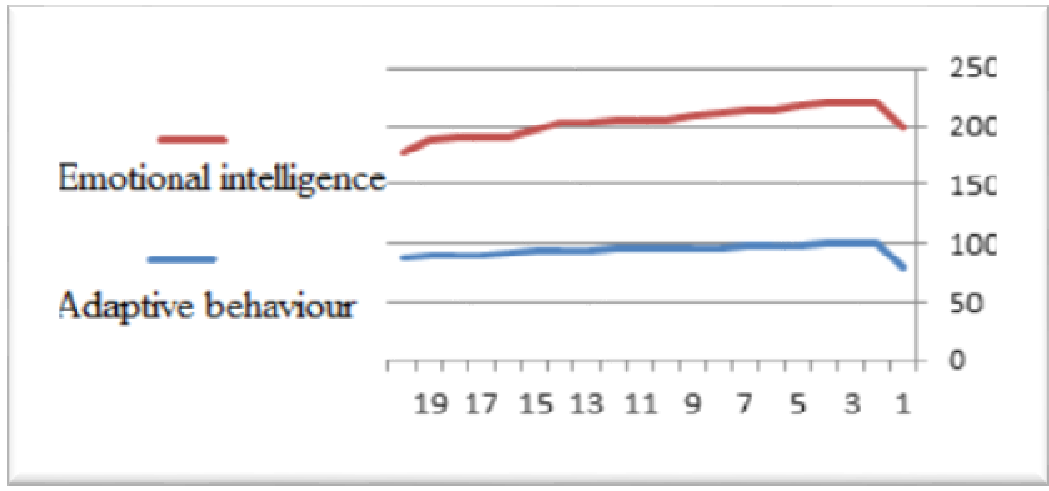

Figure (5) A diagram showing the correlation between the scores of the experimental group 